\begin{tabular}{|l|l|l||}
\hline \multicolumn{2}{|c|}{ PublisherInfo } \\
\hline \hline PublisherName & $:$ & BioMed Central \\
\hline \hline PublisherLocation & $:$ & London \\
\hline \hline PublisherImprintName & $:$ & BioMed Central \\
\hline \hline
\end{tabular}

\title{
Skin deep
}

\begin{tabular}{|l|l|l||}
\hline \multicolumn{2}{|c|}{ ArticleInfo } \\
\hline \hline ArticleID & $:$ & 4696 \\
\hline \hline ArticleDOI & $:$ & $10.1186 /$ gb-spotlight-20030211-01 \\
\hline \hline ArticleCitationID & $:$ & spotlight-20030211-01 \\
\hline \hline ArticleSequenceNumber & $:$ & 48 \\
\hline \hline ArticleCategory & $:$ & Research news \\
\hline ArticleFirstPage & $:$ & 1 \\
\hline \hline ArticleLastPage & $:$ & 2 \\
\hline \hline & & RegistrationDate : 2003-2-11 \\
\hline ArticleHistory & $:$ & OnlineDate \\
\hline \hline ArticleCopyright & $:$ & BioMed Central Ltd2003 \\
\hline \hline ArticleGrants & $:$ & \\
\hline \hline ArticleContext & $:$ & 130594411 \\
\hline \hline
\end{tabular}




\section{Jonathan B Weitzman}

Email: jonathanweitzman@hotmail.com

Fundamental differences between human and mouse skin, and differences in cellular transformation, pose a challenge to the development of useful models for studying skin diseases and malignancies. In the February 6 Nature Maya Dajee and colleagues at Stanford University School of Medicine in California describe experiments in normal epidermal cells that demonstrate the roles of oncogenic Ras and NFKB pathways in neoplastic transformation (Nature 2003, 421:639-643). They used an animal model in which normal human skin is grafted onto the back of immunodeficient scid mice. They delivered a series of oncogenic genes to human keratinocytes using retroviral infections. Co-expression of oncogenic Ras and a stable repressor mutant of $\mathrm{I} \mathrm{KB} \alpha$ induced large neoplasms similar to human squamous cell carcinoma (SCC). The tumors displayed several SCC characteristics including an elevated mitotic index. Blocking NFKB activity appears to overcome Ras-induced growth arrest and induces the expression of high levels of the protein kinase CDK4. Dajee et al. also demonstrate the importance of the human integrin $\alpha_{6} \beta_{4}$ in the skin tumorigenesis process.

\section{References}

1. Nature, [http://www.nature.com]

2. Stanford University School of Medicine, [http://www.med.stanford.edu/]

3. Ras and Rho regulation of the cell cycle and oncogenesis.

4. NF- $\mathrm{KB}$ in cancer: from innocent bystander to major culprit. 